\title{
HUBUNGAN TINGKAT PENGETAHUAN DENGAN KEPATUHAN PENGOBATAN MASSAL FILARIASIS DI KECAMATAN BAKTIYA ACEH UTARA
}

\author{
Yuziani $^{1}$, Mulyati Sri Rahayu ${ }^{2}$, Wizar Putri Mellaratna ${ }^{3}$ \\ 1) Program Studi Pendidikan Dokter, Fakultas Kedokteran, Universitas Malikussaleh \\ Corresponding author: yuziani@unimal.ac.id
}

\begin{abstract}
Abstrak
Filariasis atau kaki gajah adalah penyakit menular menahun yang disebabkan oleh cacing filarial, yang menimbukan pembengkakan pada tangan, kaki dan genital. Filariasis masih menjadi salah satu masalah kesehatan masyarakat di Kabupaten Aceh Utara, salah satunya di Kecamatan Baktiya menjadi angka kejadian tertinggi. Salah satu strategi pemberantasan filariasis yang dilakukan dengan memutuskan mata rantai penularan dengan Pemberian Obat Masal Pencegahan (POMP) filariasis. Penelitian bertujuan mengetahui hubungan tingkat pengetahuan tentang filariasis terhadap kepatuhan pengobatan massal filariasis di Kecamatan Baktiya Aceh Utara. Jenis penelitian ini adalah analitik observasional dengan menggunakan pendekatan crosssectional, sampel yang digunakan pada penelitian ini sebanyak 256 sample dan analisis data menggunkan uji Chi-Square dan Uji Kolmogorov Smirnov sebagai alternatif lain untuk pemenuhan syarat. Hasil penelitian menunjukan tidak ada hubungan tingkat pengetahuan dengan kepatuhan pengobatan massal filariasis. Kesimpulan dari penelitian ini adalah tidak didapatkan hubungan yang significan antara tingkat pengetahuan masyarakat di wilayah kecamatan Baktiya Aceh Utara terhadap kepatuhan pengobatan pencegahan massal filariasis yang telah dilaksanakan di wilayah tersebut.
\end{abstract}

Kata kunci : Filariasis, Pengetahuan, Pemberian Obat Massal Pencegahan (POMP).

\section{The Relationship Of Community Attitude With Compliance With Mass Filariasis Treatment In Baktiya District, Aceh Utara}

\begin{abstract}
Filariasis or elephantiasis is a chronic infectious disease caused by of filarial worms, it causes swelling of the hands, feet, and genitals. Filariasis is still one of the public health problems in North Aceh Regency, one of which is in Baktiya Sub-district, the highest incidence. One of the filariasis eradication strategies is done by breaking the chain of transmission by Administration of Mass Medication in Preventionof (POMP)Filariasis. The study aims to determine the association between level of knowledge about filariasis and compliance of filariasis mass treatment in Baktiya Subdistrict, North Aceh. The type of research is observational analytic using a crosssectional approach, the sample used in this study are 256 samples, and the test used for data analysis are Chi-Square Test and Kolmogorov Smirnov's Test as another alternative
\end{abstract}


for compliance. The results show that there is no association between level of knowledge and compliance of filariasis mass treatment. The conclusion of this study is that there is no association between level of knowledge and compliance of filariasis mass treatment in Baktiya Sub-district, North Aceh.

Keywords: Filariasis, Knowledge, Administration of Mass Medication in Prevention of (POMP)

\section{PENDAHULUAN}

Filariasis atau kaki gajah adalah penyakit menular menahun yang disebabkan oleh parasit berupa cacing filaria, dan merupakan penyakit tropis yang terabaikan (Negleted Tropical Diseases atau NTD). Di Indonesia, diketahui 3 spesies cacing filaria yaitu: Wuchereria bancrofti, Brugia malayi dan Brugia timori. Infeksi cacing filaria ke tubuh manusia melalui gigitan nyamuk yang berperan sebagai vektor. Penyakit ini menyerang saluran dan kelenjar getah bening dan kemudian dapat merusak sistem limfe, menimbulkan pembengkakan pada tangan, kaki, glandula mammae, dan scrotum, menimbulkan cacat seumur hidup serta stigma sosial bagi penderita dan keluarganya (Kemenkes RI, 2014).

Data dari World Health Organization tahun 2009 menunjukkan bahwa Filariasis telah menginfeksi 120 juta penduduk di 83 negara di seluruh dunia, terutama negaranegara di daerah tropis dan beberapa daerah subtropis. Filariasis menyebar di seluruh wilayah indonesia, di beberapa daerah mempunyai tingkat endemisitas yang cukup tinggi. Berdasarkan data yang dilaporkan oleh dinas kesehatan provinsi dan hasil survey di Indonesia, kasus kronis filariasis dari tahun 2002 hingga tahun 2015 terus meningkat, dimana pada tahun 2015, terdapat 13.032 kasus. Data juga menyebutkan bahwa provinsi dengan jumlah klinis filariasis terbanyak yaitu Nusa Tenggara Timur (2.864), Aceh (2.372), dan Papua Barat (1.244 orang) (Dinkes RI, 2016).

Berdasarkan data yang diperoleh dari Profil Kesehatan Aceh Utara pada tahun 2017 diketahui bahwa jumlah seluruh kasus Filariasis di Kabupaten Aceh Utara pada tahun 2017 sebanyak 103 kasus. Kasus tertingi terdapat di Kecamatan Baktiya yakni 21 kasus, kemudian diikuti oleh kecamatan Nisam dengan 14 kasus. Angka kesakitan filariasis juga ikut naik pada tahun 2017 sebesar 17 per 100.000 penduduk.

World Health Assembly menetapkan resolusi "Elimination of Lymphatic Filariasis as a Public Health Problem", yang kemudian pada tahun 2000 diperkuat dengan 
keputusan WHO dengan mendeklarasikan "The Global Goal of Lymphatic Filariasis as a Public Health Problem by the Year 2020". Indonesia sepakat untuk ikut serta dalam eliminasi filariasis global yang ditandai dengan pencanangan dimulainya eliminasi filarisis di Indonesia oleh Menteri Kesehatan pada tanggal 8 April 2002 di Desa Mainan, Kecamatan Banyuasin III, Kabupaten Musi Banyuasin, Sumatera Selatan. Pemerintah telah menetapkan Program Eliminasi Filariasis sebagai salah satu prioritas nasional pemberantasan penyakit menular sesuai dengan Peraturan Presiden Republik Indonesia nomor 7 tahun 2005 tentang Rencana Pembangunan Jangka Menengah Nasional tahun 2004- 2009, Bab 28, D, 5. Selain itu diterbitkan Surat Edaran Mendagri No. 443.43/875/SJ tentang Pedoman Pelaksanaan Pengobatan Massal Filariasis dalam rangka Eliminasi Filariasis di Indonesia, sehingga diharapkan komitmen dari pemerintah, provinsi dan kabupaten/kota akan meningkat (2).

Untuk mempercepat terwujudnya Indonesia bebas kaki gajah, maka dicanangkanlah Bulan Eliminasi Kaki Gajah (Belkaga) pada Bulan Oktober periode Tahun 2015-2020, program ini menerapkan diharuskannya minum obat filariasis kepada setiap penduduk kabupaten/kota endemis kaki gajah secara serentak pada bulan Oktober. Belkaga telah dilaksanakan pada tanggal 1 Oktober 2015 dan diharapkan semua kabupaten/kota endemis filariasis mulai melaksanakan POPM Filariasis paling lambat tahun 2016 sehingga pada tahun 2020 rangkaian siklus POPM selama 5 tahun diharapkan selesai dilaksanakan. (Meliyanie,G \& Andiarsa,D, 2017).

Dinas Kesehatan Provinsi Aceh melalui Dinas Kesehatan kabupaten/kota juga menetapkan upaya pencegahan filariasis melalui kegiatan Belkaga yang akan dilaksanakan sampai dengan 2019, dengan target pada tahun 2020 Aceh akan menjadi daerah eliminasi Filariasis. Aceh Utara merupakan salah satu daerah endemis penyakit kaki gajah, pencanangan bulan eliminasi kaki gajah (Belkaga) di Aceh Utara dilaksanakan sejak tahun 2015 hingga tahun 2019 (Serambinews.com, 2016).

Program global filariasis dari WHO yaitu memutuskan rantai penularan filariasis, mencegah serta membatasi kecacatan, satuan lokasi pelaksanaan eliminasi filariasis adalah kabupaten/kota, dan mencegah penyebaran filariasis antar kabupaten, provinsi dan negara. Strategi yang dilakukan dalam mendukung program tersebut yaitu memutuskan rantai penularan filariasis melalui pengobatan massal di daerah endemis (POPM) dan pengendalian vektor secara terpadu (Yulidar, 2016).

Pemberian obat pencegahan secara massal filariasis adalah pemberian obat yang 
dilakukan untuk mematikan mikrofilaria secara serentak kepada semua penduduk sasaran di wilayah endemis filariasis. Obat yang digunakan dalam pengobatan massal ini adalah kombinasi Diethyl Carbamazine Citrate (DEC) dosis tunggal 6mg/kg berat badan, Albendazol 400 mg (1 tablet) dan Paracetamol (sesuai takaran) (Purwantyastuti, 2010).

Tujuan Kegiatan POPM Filariasis yakni terselenggaranya kegiatan POPM Filariasis yang terencana dengan baik terhadap seluruh penduduk sasaran di daerah endemis filariasis (Kabupaten/Kota Endemis Filariasis) dengan cakupan lebih dari 85\% jumlah penduduk sasaran pengobatan dan $65 \%$ dari jumlah penduduk total, sehingga dapat menurunkan angka microfilaria rate menjadi $<1 \%$, menurunnya kepadatan rata-rata mikrofilaria dan terputusnya rantai penularan Filariasis. Adapun sasaran dari kegiatan POPM Filariasis ini dilaksanakan terhadap semua penduduk usia 2 tahun sampai dengan usia 70 tahun di seluruh wilayah Kabupaten/Kota Endemis filariasis (Kemenkes RI, 2014).

Situasi program eliminasi filariasis hingga pada tahun 2015 dari 514 kabupaten/kota di Indonesia terdapatnya 239 kabupaten/kota endemis filariasis, hanya 132 kabupaten/kota yang melaksanakan POPM filariasis dan masih ada 58 kabupaten/kota endemis yang belum melaksanakan POPM filariasis dikarenakan berbagai kendala. Data menunjukkan adanya penurunan cakupan POPM pada tahun 2015 dibandingkan tahun 2014. Pada tahun 2015, cakupan POPM sebesar 69,52 \% turun dari tahun 2014 (73,91\%). Penurunan ini disebabkan karena jumlah penduduk di kabupaten/kota endemis meningkat, selain jumlah kabupaten/kota endemisnya juga meningkat dibandingkan dengan tahun 2014 (3).

Data dari dinas kesehatan Aceh pada tahun 2017 menyebutkan bahwa cakupan pengobatan filariasis yang masih kurang dari $65 \%$ berada di Kabupaten Nagan Raya, Aceh Barat, Aceh Timur, dan Kabupaten Aceh Utara, sedangkan untuk kabupaten Singkil dan Subulussalam cakupan pengobatan mencapai di atas $65 \%$.

Ada beberapa faktor yang nantinya akan berpengaruh terhadap kepatuhan pengobatan POPM filariasis. Penelitian yang dilakukan Ahdy,MGR (2015) membuktikan bahwa ada hubungan antara pengetahuan tentang pencegahan filariasis dengan praktek minum obat filariasis. Oleh karena itu untuk meningkatkan kualitas POPM filariasis di Aceh Utara, perlu diketahui apakah ada hubungan pengetahuan masyarakat tentang filariasis terhadap kepatuhan pengobatan massal filariasis pada 
masyarakat di daerah endemis filariasis pada masyarakat di Kecamatan Baktiya, Aceh Utara.

\section{METODE PENELITIAN}

Penelitian ini menggunakan desain penelitian analitik observasional dengan pendekatan Cross Sectional, karena pengukuran variabel bebas tingkat pengetahuan masyarakat dengan variabel terikat kepatuhan pengobatan massal filariasis dilakukan sekali waktu pada saat yang bersamaan. Penelitian dilaksanakan di Kecamatan Baktiya, Aceh Utara, yang terdiri dari 57 desa.

Semua anggota populasi yang dalam hal ini yang memenuhi kriteria inklusi dan eksklusi. Dimana kriteria Inklusi adalah pria dan wanita berusia 18-60 tahun.Pria dan wanita yang berdomisili tetap di Kecamatan Baktiya, Aceh Utara selama kurun waktu berjalanya progam pencegahan filariasis, dan bersedia menjadi subjek penelitian, sedangkan kriteria eksklusi adalah wanita yang sedang hamil dan penderita filariasis klinis kronis.

Teknik pengambilan sampel menggunakan rumus Lameshow dengan besar sampel minimal yang diteliti adalah 256 orang dari 57 desa di Kecamatan Baktiya, Aceh Utara. Sampel dipilih dengan menggunakan teknik probability sampling dengan cara stratified random sampling. Pengambilan teknik ini dilakukan karena sampel yang terdiri dari beberapa kelompok dengan jumlah yang berbeda. Jumlah masyarakat yang menjadi sampel penelitian pada setiap desa dihitung dengan menggunakan rumus proposional random sampling.

Data yang telah dikumpulkan, diolah dengan menggunakan program SPSS untuk di analisis dengan langkah editing, coding, entry, cleaning, tabulating, computing dengan melakukan analisis data univariat dan bivariat.

\section{HASIL}

\section{Hasil Penelitian dan Analisis}

1. Distribusi Responden Menurut Umur

Tabel 1 Distribusi Frekuensi Responden Menurut Umur

\begin{tabular}{lll}
\hline Umur & Frekuensi (n) & Persentase (\%) \\
\hline
\end{tabular}




\begin{tabular}{|c|c|c|}
\hline $17-25$ & 111 & 43,3 \\
\hline $26-35$ & 48 & 18,8 \\
\hline $36-45$ & 58 & 22,7 \\
\hline $46-55$ & 33 & 12,9 \\
\hline $56-65$ & 6 & 2,3 \\
\hline Total & 256 & 100,0 \\
\hline
\end{tabular}

(Sumber: Data Primer, 2020)

Berdasarkan table 1 didapatkan bahwa distribusi frekuensi responden menurut umur terrbanyak pada umur 17-25 yaitu 43,4\%, dan yang terendah terdapat pada umur 56-65 yaitu 2,3\%.

2. Distribusi Responden Menurut Jenis Kelamin

Tabel 2 Distribusi Frekuensi Responden Menurut Jenis Kelamin

\begin{tabular}{|c|c|c|}
\hline Jenis Kelamin & Frekuensi (n) & Persentase (\%) \\
\hline Laki-laki & 134 & 52,3 \\
\hline Perempuan & 122 & 47,7 \\
\hline Total & 256 & 100,0 \\
\hline
\end{tabular}

(Sumber: Data Primer, 2020)

Berdasarkan tabel 2 didapatkan bahwa responden yang berjenis kelamin Laki-laki sebanyak 52,3 \% dan responden yang berjenis kelamin perempuan sebanyak $47,7 \%$.

3. Distribusi Responden Menurut Pendidikan Terakhir

Tabel 3 Distribusi Frekuensi Responden Menurut Pendidikan Terakhir

\begin{tabular}{lcc}
\hline \multicolumn{1}{c}{ Pendidikan Terakhir } & Frekuensi (n) & Persentase (\%) \\
\hline Tamat SD & 32 & 12,5 \\
Tamat SMP/Mts & 48 & 18,8 \\
Tamat SMA/MA/SMK & 134 & 52,3 \\
Tamat Perguruan Tinggi & 42 & 16,4 \\
\hline \multicolumn{1}{c}{ Total } & 256 & 100,0
\end{tabular}

(Sumber: Data Primer, 2020)

Berdasarkan tabel 3 didapatkan bahwa distribusi frekuensi responden menurut pendidikan terakhir terbanyak adalah yang tamat SMA/MA/SMK yaitu $52,3 \%$, dan yang terendah adalah tamat SD yaitu $12,5 \%$. 
4. Distribusi Responden Menurut Pekerjaan

Tabel 4. Distribusi Frekuensi Responden Menurut Pekerjaan

\begin{tabular}{|c|c|c|}
\hline Pekerjaan & Frekuensi (n) & Persentase (\%) \\
\hline Buruh & 41 & 16,0 \\
\hline PNS & 29 & 11,3 \\
\hline Pegawai Swasta & 2 & 0,8 \\
\hline Wirausaha & 47 & 18,4 \\
\hline Siswa & 13 & 5,1 \\
\hline Mahasiswa & 23 & 9,0 \\
\hline IRT & 52 & 20,3 \\
\hline Tidak Bekerja & 49 & 18,4 \\
\hline Total & 256 & 100,0 \\
\hline
\end{tabular}

(Sumber: Data Primer, 2020)

Berdasarkan tabel 4 didapatkan distribusi frekuensi responden menurut pekerjaan terbanyak adalah IRT yaitu 20,3\%, dan yang terendah adalah pegawai swasta yaitu $0,8 \%$.

Distribusi Tingkat Pengetahuan Responden

Variabel tingkat sikap didistribusikan meliputi 3 kategori, yaitu terdiri dari kurang, cukup, dan baik. Distribusi frekuensi dan persentase tingkat sikap masyarakat tentang filariasis di kecamatan Baktiya, Aceh Utara dapat dilihat pada tabel berikut.

Tabel 5. Distribusi Sikap Responden Tentang Filariasis

\begin{tabular}{|c|c|c|}
\hline Pengetahuan & Frekuensi (n) & Persentase (\%) \\
\hline Baik & 34 & 13,3 \\
\hline Cukup & 107 & 41,8 \\
\hline Kurang & 115 & 44,9 \\
\hline Total & 256 & 100,0 \\
\hline
\end{tabular}

(Sumber: Data Primer, 2020)

Berdasarkan tabel 5 didapatkan responden yang mempunyai tingkat pengetahuan baik tentang filariasis sebanyak 13,3\%, yang mempunyai tingkat pengetahuan cukup tentang filariasis sebanyak 41,8\%, dan yang mempunyai 
tingkat pengetahuan kurang tentang filariasis sebanyak 44,9\%.

6. Distribusi Kepatuhan Responden

Tabel 6. Distribusi Kepatuhan Responden Pada Pengobatan Massal Filariasis

\begin{tabular}{|c|c|c|}
\hline Kepatuhan Minum Obat & Frekuensi (n) & Persentase (\%) \\
\hline Tidak patuh & 249 & 97,3 \\
\hline Patuh & 7 & 2,7 \\
\hline Total & 256 & 100,0 \\
\hline
\end{tabular}

(Sumber: Data Primer, 2020)

Berdasarkan tabel 6 didapatkan responden yang patuh minum obat filariasis adalah hanya $2,7 \%$, dan yang tidak patuh sebanyak $97,3 \%$.

7. Hubungan tingkat sikap dengan kepatuhan pengobatan massal filariasis

Analisis bivariat digunakan untuk menjelaskan hubungan antara variabel independent dengan variabel dependent dalam penelitian ini. Variabel independent yang akan dilakukan analisis secara bivariat dalam penelitian ini adalah tingkat sikap masyarakat, sedangkan untuk variabel dependent nya adalah kepatuhan pengobatan massal filariasis. Uji statistic yang digunakan dalam analisis ini adalah crosstab dengan uji chi square dan uji Kolmogorov Smirnov.

Tabel 7 Analisis tingkat sikap dengan kepatuhan pengobatan massal filariasis

\begin{tabular}{|c|c|c|c|c|c|c|c|}
\hline \multirow{3}{*}{$\begin{array}{c}\text { Tingkat } \\
\text { Pengetahuan }\end{array}$} & \multicolumn{6}{|c|}{ Kepatuhan pengobatan massal filariasis } & \multirow{3}{*}{ P-value } \\
\hline & \multicolumn{2}{|c|}{ Tidak Patuh } & \multicolumn{2}{|c|}{ Patuh } & \multicolumn{2}{|c|}{ Total } & \\
\hline & $\mathbf{n}$ & $\%$ & $\mathbf{n}$ & $\%$ & $\mathbf{n}$ & $\%$ & \\
\hline Baik & 32 & 12,9 & 2 & 28,6 & 34 & 13,3 & \\
\hline Cukup & 105 & 42,2 & 2 & 28,6 & 107 & 41,8 & 0.996 \\
\hline Kurang & 112 & 45,0 & 3 & 42,9 & 115 & 44,9 & \\
\hline Total & 249 & 100 & 7 & 100 & 256 & 100 & \\
\hline
\end{tabular}

(Sumber: Data Primer, 2020)

Berdasarkan tabel 7 dengan menggunakan uji Chi-Square diketahui bahwa dari 115 responden (44,9\%) yang tingkat pengetahuannya kurang, terdapat 
112 responden $(45,0 \%)$ yang kepatuhan minum obat massal filariasisnya tidak patuh, dan 3 responden (42,9\%) yang kepatuhan minum obat massal filariasisnya patuh. Hasil juga menunjukkan bahwa dari 107 responden $(41,8 \%)$ yang tingkat pengetahuannya cukup, terdapat 105 responden (42,2 \%) yang kepatuhan minum obat massal filariasisnya tidak patuh, dan 2 responden $(28,6 \%)$ yang kepatuhan minum obat massal filariasisnya patuh. Sedangkan dari 34 responden $(13,3 \%)$ yang tingkat pengetahuannya baik, terdapat 32 responden $(12,9 \%)$ yang kepatuhan minum obat massal filariasisnya tidak patuh, dan 2 responden $(28,6 \%)$ yang kepatuhan minum obat massal filariasisnya patuh.

Berdasarkan uji Kolmogorov Smirnov menunjukkan bahwa pada penelitian ini Ho diterima $\mathrm{p}=0,996(>0.05)$ sehingga Ha ditolak. Hal ini menunjukkan tidak terdapat hubungan antara tingkat pengetahuan dengan kepatuhan pengobatan massal filariasis pada masyarakat di kecamatan Baktiya Aceh Utara.

\section{PEMBAHASAN}

Hasil dari penelitian ini menunjukkan bahwa jumlah responden penelitian dengan rentang umur terbanyak adalah berada pada usia 17-25 yaitu 43,4 \%, responden pada rentang usia ini terdiri dari siswa, mahasiswa, dan responden yang memilih tidak melanjutkan pendidikan setelah SMA, ini menunjukkan bahwa sebagian besar penduduknya berada pada usia produktif, dan lebih sering ditemui ketika penelitian berlangsung, menurut data statistik kecamatan setempat juga menyebutkan bahwa jumlah penduduk berdasarkan kelompok umur tertinggi pada kelompok usia produktif.

Berdasarkan distribusi jenis kelamin, mayoritas responden pada penelitian ini adalah jenis kelamin laki-laki yaitu 52,3\%, selisih angka jenis kelamin antara laki-laki dan perempuan hanya $5 \%$, sampel terdistribusi rata berdasarkan jenis kelamin, ini sesuai dengan distribusi jumlah penduduk berdasarkan jenis kelamin berdasarkan koordinator statistik kecamatan setempat.

Hasil yang didapatkan dari distribusi pendidikan terakhir responden didapatkan bahwa jenjang pendidikan terakhir responden terbanyak adalah tamat SMA/MA/SMK adalah 52,3 \%. Hal ini menunjukkan bahwa jenjang pendidikan penduduk rata-rata sudah berada pada level menengah yang menggambarkan 
bahwa setiap tindakan dan perilaku penduduk tidak hanya sebatas perilaku tanpa pemikiran yang matang. Pendidikan dapat membawa wawasan atau pengetahuan seseorang.

Sebagian besar responden dari penelitian ini adalah IRT yaitu sebanyak 20,3 \% dimana saat dilakukan wawancara, yang berhasil banyak ditemui dan bersedia di wawancara adalah ibu-ibu rumah tangga, karena sebagian besar responden berada di rumah mereka saat penelitian dilakukan, berbeda dengan responden-responden lain yang bekerja.

\section{Tingkat Pengetahuan Masyarakat Tentang Filariasis}

Hasil penelitian untuk tingkat pengetahuan menunjukkan bahwa sebagian besar responden memiliki tingkat pengetahuan yang kurang tentang filariasis yaitu sebanyak 44,9\%, kemudian diikuti oleh tingkat pengetahuan yang cukup yaitu sebanyak $41,8 \%$, dan sisanya hanya $13,3 \%$ yang memiliki tingkat pengetahuan baik tentang filariasis. Dari hasil tersebut dapat digambarkan bahwa masih sedikitnya responden yang memiliki pengetahuan yang baik secara teori tentang filariasis dan program pengobatan pencegahan filariasis.

Hasil ini sama dengan penelitian yang dilakukan oleh Dewi Kusumawardani (2009) pada penelitian Gambaran Faktor-faktor Predisposisi Praktik Minum Obat Pada Pengobatan Massal Filariasis di 7 RW Kelurahan Baktijaya Depok tahun 2009, dimana didapatkan bahwa sebagian besar responden memiliki pengetahuan yang kurang tentang filariasis yaitu sekitar 83,9 $\%$, dan hanya 16, $1 \%$ yang memiliki pengetahuan baik. Begitupun dengan penelitian yang dilakukan Suherni (2007) yang pada penelitiannya, proporsi responden dengan pengetahuan kurang baik lebih tinggi dari responden yang berpengetahuan baik.

Pengetahuan dianggap baik jika faktor terhadap pengertian filariasis, tanda gejala filariasis, vektor atau agen penular, dan pencegahan filariasis mendapatkan nilai lebih dari $75 \%$ dari semua total nilai. Pada pengetahuan cukup kebanyakan responden hanya mengetahui sampai faktor vektor, sedangkan pada faktor pencegahan masih belum mencapai nilai target. Sedangkan pada responden berpengetahuan kurang kebanyakan hanya paham pada faktor pengertian dan tanda gejala.

Hasil penelitian Bahtiar. S (2017) mengemukakan bahwa rendahnya 
pengetahuan tentang filariasis adalah hal yang sangat umum dan merata di berbagai daerah dan Negara. Untuk mendapatkan partisipasi aktif dari masyarakat dalam pengobatan massal Filariasis, maka diperlukan pengetahuan yang baik tentang Filariasis dan obat anti filariasis di masyarakat.

Banyaknya responden dengan pengetahuan kurang disebabkan karena kurangnya sosialisasi atau penyuluhan tentang filariasis yang masyarakat dapatkan dari petugas puskesmas setempat. Pada responden dengan tingkat pengetahuan cukup tentang filariasis lebih sering terpapar dengan informasi tentang filariasis dari media elektronik dan internet.

Selain dari media elektronik, pengetahuan responden tentang filariasis sebagian besar harusnya berasal dari kader dan petugas kesehatan. Kader merupakan ujung tombak dalam kelancaran kegiatan POMP, hal ini bisa dipahami karena kader berada di lapangan yang setiap saat dapat memberi motivasi sasaran untuk lebih memahami manfaat POMP sehingga responden mau datang ke pos pengobatan dan minum obat. Dukungan kader, tokoh masyarakat dan petugas kesehatan sangat dibutuhkan untuk keberhasilan eliminasi filariasis dalam hal penyebaran informasi atau pengetahuan kepada masyarakat, sehingga perlunya meningkatkan pengetahuan kader dan petugas kesehatan. Sosialisasi biasanya didukung dengan adanya berbagai perkumpulan di masyarakat sehingga informasi tersampaikan dengan baik. Upaya eliminasi filariasis berbasis masyarakat menghasilkan cakupan pengobatan tinggi dipengaruhi oleh tingginya sosialisasi kepada masyarakat tentang program eliminasi filariasis. Sosialisasi dibutuhkan untuk meningkatkan pengetahuan masyarakat tentang filariasis serta meningkatkan kesadaran untuk mencegah penyakit memalui POMP filariasis.

\section{Kepatuhan Masyarakat Terhadap Pengobatan Massal Filariasis}

Berdasarkan hasil penelitian dari 256 responden didapatkan hanya 2,7\% yang patuh minum obat filariasis, sedangkan sisanya yaitu 97,3\% lainnya diketahui tidak patuh dalam mengkonsumsi obat massal filariasis. Dari 7 responden yang patuh dalam pengobatan filariasis tersebut terdiri dari berbagai jenjang pendidikan dan pekerjaan. Jenis kepatuhan dibagi menjadi kepatuhan penuh, dan sama sekali tidak patuh, dalam hal ini, masyarakat yang tidak patuh dan tidak mengkonsumsi obat yang diberikan termasuk dalam kategori sama sekali tidak patuh. Ketidakpatuhan pada penelitian ini dapat dilihat dari 
bagaimana responden menerima dan meminum obat yang telah dibagikan.

Dari hasil penelitian ini didapatkan bahwa ketidakpatuhan responden dalam mengkonsumsi obat filariasis ini dikarenakan responden takut akan efek samping yang ditimbulkan obat tersebut, dan karena responden merasa tidak sakit sehingga tidak perlu untuk mengkonsumsinya, kurangnya penyuluhan secara intensif dari dinas kesehatan terkait dan informasi tentang filariasis membuat banyak responden yang tidak menghadiri pos pembagian obat massal tersebut. Dari analisis lapangan juga ddidapatkan bahwa banyak responden yang tidak meminum obat secara langsung di depan petugas saat pembagian obat.

Faktor manfaat keyakinan seseorang akan manfaat atau kemanjuran dari pengobatan akan berpegaruh terhadap kepatuhan pengobatan, dimana dari hasil wawancara yang dilakukan peneliti didapatkan bahwa masyarakat mempunyai kepercayaan bahwa tidak minum obat filariasis pun tidak beresiko pada dirinya, masyarakat juga merasa tidak perlu mengonsumsi obat jika tidak merasakan gejala, sehingga pada akhirnya menurunkan kepatuhan dalam pengobatan massal filariasis

Beberapa peneliti melaporkan adanya hubungan erat antara kepatuhan pasien berobat dengan bebrapa faktor lainnya seperti efek samping obat (Wibowo dan Soepardi 2008), penelitian tersebut sejalan dengan penelitian ini, dimana berdasarkan hasil wawancara, adanya efek samping yang ditimbulkan oleh obat pencegahan filariasis membuat responden merasa takut untuk meminum obat tersebut karena banyaknya aktivitas yang dilakukan sehingga akan meghambat pekerjaan responden, ini dikaitkan dengan karakteristik responden didapatkan bahwa kebanyakan responden pada penelitian ini berada pada usia produktif, mayoritas responden dengan usia produktif jika terserang penyakit akan merasa aktivitas kesehariannya terganggu.

Hasil pengamatan peneliti juga didapatkan bahwa petugas kesehatan setempat kurang memberikan sosialisasi, petugas kesehatan seharusnya mengadakan sosialisasi kepada masyarakat untuk meningkatkan pengetahuan tentang penyakit filariasis. Sehingga masyarakat yang berpengetahuan kurang dan cukup pun tentang filariasis melaksanakan pengobatan dan menyikapi dengan benar apabila terjadi reaksi pengobatan.

Selanjutnya petugas kesehatan juga jarang mendistribusikan obat filariasis 
ke rumah -rumah di desa/kelurahan, sehingga petugas tidak dapat memastikan bahwa obat-obat yang diberikan dalam pencegahan massal filariasis dikonsumsi atau tidak oleh penerima obat, distribusi obat filariasis hanya pada pos pembagian obat saja, dari hasil wawancara juga didapatkan bahwa ada responden yang tidak langsung meminum obat tersebut di depan petugas.

\section{Hubungan Antara Tingkat Pengetahuan Masyarakat Dengan Kepatuhan Pengobatan Massal Filariasis}

Berdasarkan hasil penelitian yang sudah dilakukan di kecamatan Baktiya Aceh Utara, menunjukkan bahwa tidak ada hubungan antara tingkat pengetahuan masyarakat dengan kepatuhan pengobatan massal filariasis pada masyarakat di Kecamatan Baktiya. Hasil penelitian menunjukkan bahwa responden yang memiliki tingkat pengetahuan yang cukup mengenai filariasis tidak membuat responden patuh terhadap pengobatan, ini dikarenakan alasan responden yang takut mengkonsumsi obat filariasis karena efek samping yang ditimbulkan, dan juga merasa tidak sakit sehingga tidak perlu meminum obat filariasis.

Hasil penelitian ini sesuai dengan penelitian Amnur,RS (2018) tentang Hubungan pengetahuan dan sikap dengan praktek minum obat dalam program(POMP) filariasis pada masyarakat Desa Sebakung Jaya RT.10 Kabupaten Penajam Paser Utara yang dilakukan pada tahun 2018 juga menunjukkan tidak ada hubungan antara pengetahuan dengan praktek minum obat.

Penelitian tersebut mengatakan bahwa tindakan praktek minum obat POMP filariasis baik tidak harus didasari dengan pengetahuan tentang pencegahan filariasis yang baik pula, bisa didasari dengan kewajiban dari daerah tersebut, atau kesadaran masyarakat itu sendiri yang hidup terpapar dengan orang yang sudah positif filariasis.

Hasil penelitian ini juga didukung oleh penelitian Rusmanto (2013) tentang Faktor-faktor yang mempengaruhi sikap dan perilaku masyarakat terhadap kepatuhan minum obat anti filarial di RW II Kelurahan Pondok Aren, yang menyatakan bahwa tidak ada hubungan yang bermakna antara pengetahuan dengan sikap kepatuhan minum obat filariasis dikarenakan petugas kesehatan tidak memberikan pendidikan kesehatan secara menyeluruh kepada semua kelompok umur melainkan hanya kepada ibu-ibu pengajian dan perkumpulan 
warga sehingga masyarakat kelompok remaja tidak mendapatkan pendidikan kesehatan dari petugas kesehatan melainkan dari sekolah atau media massa.

Hasil penelitian Puji Astuti E et al tahun 2013 juga menunjukkan bahwa tingkat pengetahuan responden tentang filaria dan pengobatannya tidak berhubungan dengan kepatuhan masyarakat dalam minum obat di Kabupaten Bandung, namun yang mempunyai pengaruh adalah praktek responden dalam pencegahan, dan pengendalian terhadap kepatuhan minum obat di kecamatan Majalaya Kabupaten Bandung.

Penelitian yang telah dilakukan peneliti menunjukkan bahwa kurangnya pengetahuan masyarakat terhadap filariasis di Kecamatan Baktiya Aceh Utara berimbas ke kepatuhan pengobatan filariasis di wilayah tersebut, data juga menyebutkan wilayah tersebut menjadi wilayah dengan angka kejadian filarisis terbanyak di Aceh Utara, hasil penelitian Riskesdas 2018 menunjukkan Aceh dengan angka filariasis terbanyak ketiga setelah Maluku dan Papua pada tahun 2018, untuk hasil dari cakupan pengobatan program Pemberian Obat Massal Pencegahan (POMP) filariasis di Aceh hanya mencapai $60 \%$ dari cakupan pengobatan.

Cakupan pengobatan yang rendah salah satu faktor penyebab kegagalan program eliminasi filariasis di suatu wilayah. Berbagai alasan atas rendahnya cakupan ini antara lain petugas yang tidak menyaksikan langsung masyarakat meminum obatnya, ketakutan akan efek samping obat, masyarakat merasa tidak sakit sehingga tidak harus meminum obat tersebut, dan sebagainya. Hal tersebut disebabkan karena kurangnya informasi dari petugas tentang pentingnya pengobatan massal ini sehingga tidak menjadi perhatian penting bagi masyarakat.

Pengobatan massal yang panjang dan dilakukan setiap tahun menimbulkan beberapa keluhan dan kejenuhan masyarakat yang dilibatkan, hal ini menyebabkan rendahnya cakupan pengobatan di suatu wilayah, edukasi dan kampanye secara terus menerus pada masyarakat di sekitar dapat meningkatkan kesadaran tentang pengobatan massal ini. Masyarakat yang mengetahui secara langsung dari petugas manfaat pengobatan massal akan dengan sadar dan sukarela terlibat langsung dalam program pengobatan (Meliyanie. G \& Andiarsa D (2017).

Menurut Notoatmodjo (2003), Definisi tindakan adalah gerak /perbuatan dari tubuh setelah mendapat rangsangan ataupun adaptasi dari dalam tubuh 
maupun dari luar tubuh atau lingkungan. Tindakan seseorang terhadap stimulus tertentu akan banyak ditentukan oleh bagaimana pengetahuan, kepercayaan dan perasaannya terhadap stimulus tersebut.

Pengetahuan adalah domain yang sangat penting untuk terbentuknya perilaku seseorang. Semakin baik pengetahuan seseorang, maka diharapkan akan semakin positif sikap yang ditunjukan terhadap sesuatu hal dan sikap itu akan diwujudkan dalam bentuk positif pula. Dalam pengobatan massal, ada kalanya masyarakat takut terhadap efek samping obat dan lain sebagainya sehingga menolak untuk meminum obat tersebut, hal ini merupakan bagian dari tingkat pengetahuan yang masih rendah. Pengetahuan juga merupakan faktor predisposi seseorang untuk melakukan perubahan perilaku. Faktor tersebut diharapkan dapat berpraktik baik dalam konsumsi obat kaki gajah. (Kusumawardani. D (2009).

\section{Kesimpulan}

1. Sebagian besar responden pada penelitian ini berada pada rentang umur 17-25 yaitu 43,4\%. Distribusi jenis kelamin responden pada penelitian ini hampir merata antara laki-laki dan perempuan yakni masing-masing adalah 52,3\% dan 47,7\%. Distribusi pendidikan terakhir responden terbanyak adalah tamat SMA/MA/SMK yaitu 52,3\%. Mayoritas pekerjaan responden pada penelitian ini adalah IRT yaitu sebanyak $20,3 \%$.

2. Sebagian besar distribusi tingkat pengetahuan masyarakat tentang filariasis di Kecamatan Baktiya ada pada tingkatan kurang yaitu sebanyak 44,9 \%, kemudian diikuti dengan tingkat pengetahuan yang cukup sebanyak 41,8\%, dan hanya $13,3 \%$ yang memiliki tingkat pengetahuan baik tentang filariasis.

3. Sebagian besar responden tidak patuh tehadap pengobatan massal filariasis yakni mencapai angka $97,3 \%$, dan hanya $2,7 \%$ saja yang patuh.

4. Tidak ada hubungan antara tingkat pengetahuan masyarakat dengan kepatuhan pengobatan Massal Filariasis pada masyarakat di Kecamatan Baktiya, Aceh Utara

\section{Saran}

1. Bagi masyarakat diharapkan lebih aktif dan berperan dalam mendapatkan informasi mengenai filariasis, dan mengetahui pentingnya mengkonsumsi obat pencegahan filariasis guna menurunkan angka kejadian filariasis. 
2. Bagi Puskesmas dan dinas kesehatan lebih banyak lagi melakukan penyuluhan tentang bahaya filariasis agar masyarakat paham akan filariasis, dan puskesmas diharapkan memberlakukan sistem distribusi obat antifilarial kerumah-rumah masyarakat, agar masyarakat patuh pada pengobatan massal filariasis

3. Bagi peneliti selanjutnya, hasil penelitian ini dapat dikembangkan dan dijadikan acuan untuk penelitian selanjutnya tentang hubungan tingkat pengetahuan dengan kepatuhan pengobatan massal filariasis sesuai dengan kebijakan program, serta banyak faktor lain yang mempengaruhi kepatuhan pengobatan filariasis selain dari tingkat pengetahuan masyarakat.

\section{DAFTAR PUSTAKA}

1. Kementerian Kesehatan Republik Indonesia. Peraturan Menteri Kesehatan Repubik Indonesia Nomor 94 tahun 2014, tentang Penanggulangan Filariasis. 2014;1-118.

2. A. Arsunan A. EPIDEMIOLOGI FILARIASIS. Makassar: Masagena Press; 2016. 35 p.

3. Depkes RI. Situasi Filariasis di Indonesia tahun 2015. 2016. p. 1-8.

A. Arsunan. (2016). Epidemiologi Filariasis di Indonesia. Makassar: Masagena Press.

4. Amnur,RS (2018) . Hubungan Pengetahuan dan Sikap dengan Praktek Minum Obat Dalam Program(POMP) Filariasis pada Masyarakat Desa Sebakung Jaya RT.10 Kabupaten Penajam Paser Utara. 2018.

5. Anindita, H. M. (2016). Filariasis: Pencegahan Terkait Faktor Risiko. Jurnal Kesehatan Unila.

6. Ahdy, MGR. (2015). Hubungan Pengetahuan dan Sikap Pencegahan Filariasis dengan Praktek Minum Obat Filariasis dalam Program Pemberian Obat Massal

Pencegahan (POMP) Filariasis Kelurahan Kuripan Ketoharjo Kota Pekalongan 2015.

7. Bahtiar. S (2017). Perilaku Minum Obat Anti Filariasis Di Kelurahan Rawa Mambok. Jurnal Kesehatan Stikes Kapuas Raya Sintang.

8. Balitbang Kemenkes RI. 2018. Riset Kesehatan Dasar; RISKESDAS.Jakarta: Balitbang Kemenkes RI. 